Buku Asuhan Kebidanan IV (Patologi) mencakup penatalaksanaan mola hidatidosa, KET, abortus, plasenta previa, solusio plasenta, syok, pre-eklampsia, eklampsia, asuhan kebidanan pada ibu dengan kelainan letakjanin, intervensi lanjut perdarahan postpartum, rujukan kegawatdaruratan, asuhan pada bayi baru lahir dengan asfiksia, hipoglikemi, sepsis, kejang, ikterus, serta pendokumentasian asuhan kebidanan pada kasus kegawatdaruratan. Berbagai kajian menerangkan bahwa memberikan layanan dan edukasi kebidanan merupakan hal yang esensial untuk dipelajari dan dipahami oleh petugas kesehatan khususnya bidan yang berprofesisebagai bidan pendidikmaupun bidan di pelayanan.

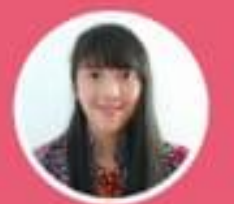

Santy Irene Putri, S.ST, MPH, lahir di Mojokerto pada tanggal $13 \mathrm{Mei}$ 1991. Telah menyelesaikan studi D3 dan D4 Kebidanan di Politeknik Kesehatan Kemenkes Malang Program Studi Kebidanan Kediri pada tahun 2012 dan 2013, serta Magister IImu Kesehatan Masyarakat UNS pada tahun 2017. Selama menempuh pendidikan, penulis bekerja sebagai staf editor pengelola jurnal Magister Ilmu Kesehatan Masyarakat. Setelah menyelesaikan pendidikan, penulis mengajar pada Program Studi Kebidanan Universitas Tribhuwana Tunggadewi Malanghingga saat ini.

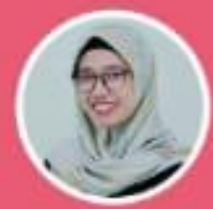

Asruria Sani Fajriah, SST, MKM. Lulus D3 Program Studi Kebidanan Kediri Politeknik Kesehatan Kemenkes Malang tahun 2014, lulus D4 Program Studi Kebidanan Pendidik UNS tahun 2016, lulus S2 di Program Studi Ilmu Kesehatan Masyarakat UNS tahun 2020. Saat ini adalah dosen tetap Program Studi Kebidanan Institut IImu Kesehatan Strada Indonesia. Pernah mengisi kuliah tamu di Politeknik Kesehatan Kemenkes Malang Program Studi Kebidanan Kediri. Sebagai Pengelola Journal for Quality in Public Health. Pernah menulis artikel jurnal penelitian yang terbit di jurnal terindeks Scopus. Pernah tampil sebagai pembicara dan moderator di beberapa seminar online kolaborasi dengan berbagaiinstitusinegeri dan swasta di Indonesia.

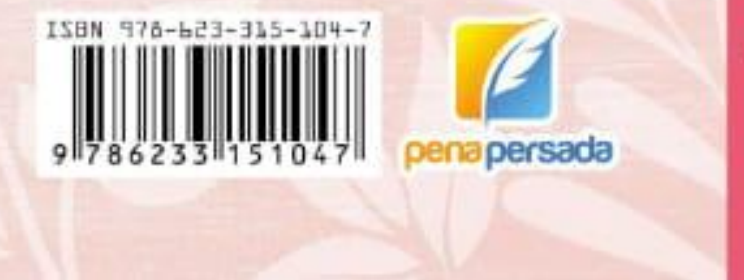

Asruria Sani Fajriah, SST., MKM
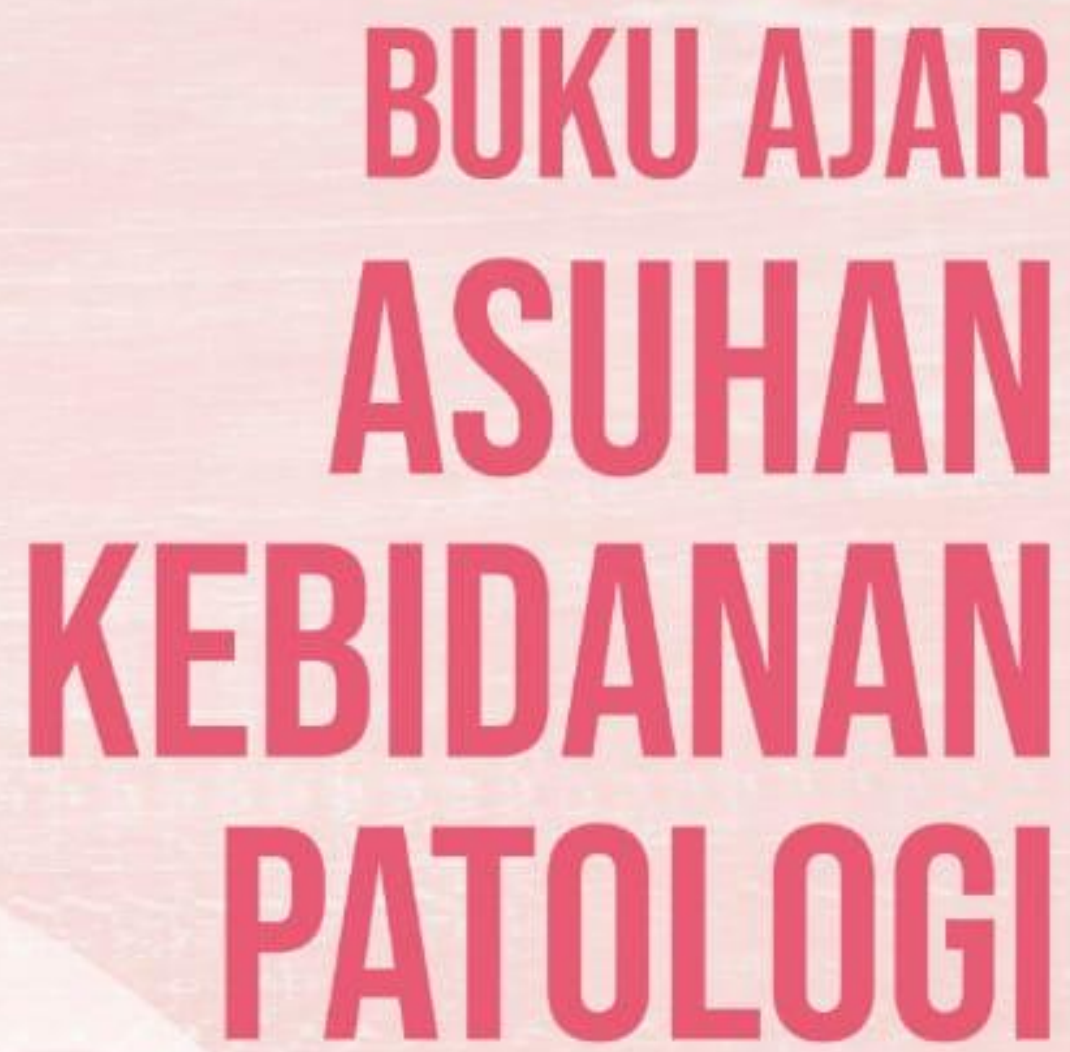


\section{BUKU AJAR \\ ASUHAN KEBIDANAN PATOLOGI}

Santy Irene Putri, S.ST, MPH

Asruria Sani Fajriah, SST., MKM

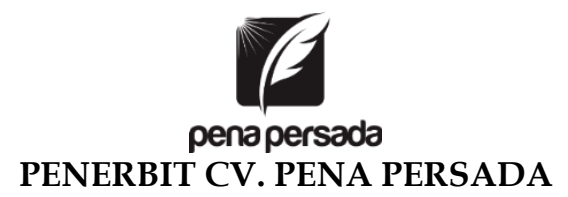




\title{
BUKU AJAR \\ ASUHAN KEBIDANAN PATOLOGI
}

\author{
Penulis: \\ Santy Irene Putri, S.ST, MPH \\ Asruria Sani Fajriah, SST., MKM \\ ISBN : 978-623-315-104-7 \\ Design Cover : \\ Retnani Nur Briliant \\ Layout : \\ Nisa Falahia \\ Penerbit CV. Pena Persada \\ Redaksi : \\ Jl. Gerilya No. 292 Purwokerto Selatan, Kab. Banyumas \\ Jawa Tengah \\ Email : penerbit.penapersada@gmail.com \\ Website : penapersada.com Phone : (0281) 7771388 \\ Anggota IKAPI \\ All right reserved \\ Cetakan pertama : 2020
}

Hak Cipta dilindungi oleh undang-undang. Dilarang memperbanyak karya tulis ini dalam bentuk apapun tanpa izin penerbit 


\section{KATA PENGANTAR}

Atas limpahan berkat Tuhan Yang Maha Esa, Buku Ajar Asuhan Kebidanan Patologi dapat diselesaikan dengan baik. Asuhan Kebidanan Patologi merupakan suatu mata kuliah yang bertujuan agar mahasiswa dapat melakukan penatalaksanaan bayi baru lahir dengan hipoglikemi, plasenta previa, solusio plasenta, syok, pre-eklampsia, eklampsia, asuhan kebidanan pada ibu dengan kelainan letak janin, intervensi lanjut perdarahan postpartum, pendokumentasian asuhan kebidanan pada kasus kegawatdaruratan, asuhan pada bayi baru lahir dengan asfiksia, hipoglikemi, sepsis, kejang, ikterus, serta dapat melakukan pendokumentasian asuhan kebidanan pada kasus kegawatdaruratan. Penyusunan buku ajar ini dimaksudkan untuk membantu serta memfasilitasi mahasiswa dalam mempelajari Asuhan Kebidanan Patologi.

Penulis mengucapkan terimakasih kepada seluruh pihak yang telah berpartisipasi serta memberikan kontribusinya dalam pengembangan bahan ajar ini. Penulis menerima kritik serta saran yang membangun untuk kebermanfaatan buku ini bagi kita semua.

Malang, Desember 2020

Penulis 


\section{DAFTAR ISI}

KATA PENGANTAR .............................................................. iii

DAFTAR ISI …..................................................................... iv

BAB 1 MOLA HIDATIDOSA, KET, ABORTUS ....................... 1

A. Kompetensi Akhir yang Diharapkan ............................ 1

B. Indikator....................................................................... 1

C. Pokok-Pokok Materi ......................................................... 1

D. Uraian Materi .................................................................... 1

1. Mola hidatidosa ......................................................... 1

2. KET …..................................................................... 2

3. Abortus ....................................................................... 3

E. Rangkuman..................................................................... 18

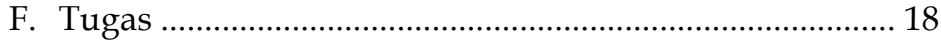

BAB 2 PLASENTA PREVIA, SOLUSIO PLASENTA ................. 19

A. Kompetensi Akhir yang Diharapkan ............................. 19

B. Indikator........................................................................ 19

C. Pokok-Pokok Materi ............................................................. 19

D. Uraian Materi ..................................................................... 19

1. Plasenta previa ........................................................... 19

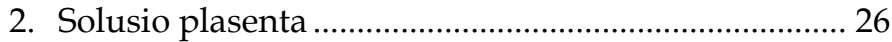

E. Panduan Belajar ......................................................... 31

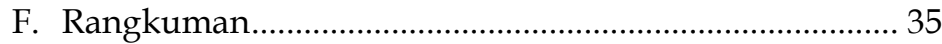

G. Kasus........................................................................... 35

BAB 3 MACAM-MACAM KELAINAN LETAK JANIN PRE-EKLAMPSIA, EKLAMPSIA .................................... 37

A. Kompetensi akhir yang diharapkan.............................. 37

B. Indikator......................................................................... 37

C. Pokok-Pokok Materi …............................................... 37

D. Uraian Materi ................................................................... 37

1. Macam-macam kelainan letak janin ......................... 37

2. Pre-eklampsia, eklampsia ....................................... 42

E. Penatalaksanaan ............................................................ 43

F. Rangkuman...................................................................... 76

G. Kasus........................................................................... 76

BAB 4 PENATALAKSANAAN SYOK ....................................... 78

A. Kompetensi akhir yang diharapkan............................... 78

B. Indikator.................................................................... 78

C. Pokok-Pokok Materi ........................................................ 78

D. Uraian Materi …............................................................ 78

E. Rangkuman................................................................... 87

F. Kasus......................................................................... 87 
BAB 5 INVERSIO UTERI, RETENSIO PLASENTA, KELAINAN PEMBEKUAN DARAH ................................ 88

A. Kompetensi akhir yang diharapkan ................................. 88

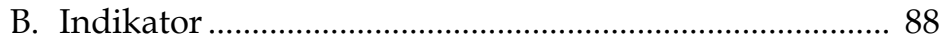

C. Pokok-Pokok Materi ……………………………........ 88

D. Uraian Materi..................................................................... 88

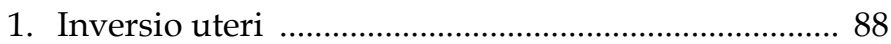

2. retensio plasenta ....................................................... 90

3. kelainan pembekuan darah ....................................... 92

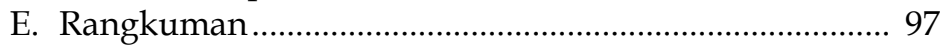

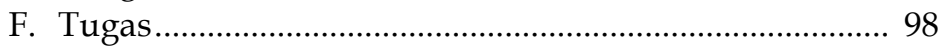

BAB 6 SISTEM DAN CARA RUJUKAN ………......................... 100

A. Kompetensi akhir yang diharapkan ................................. 100

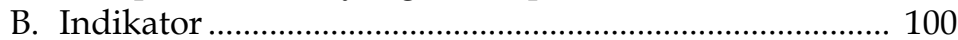

C. Pokok-Pokok Materi …………………………….............. 100

D. Uraian Materi.................................................................... 100

E. Asuhan Rujukan Kasus Gawat Darurat Maternal......... 108

F. Asuhan Rujukan Kasus Gawat Darurat Neonatal......... 110

G. Rangkuman ..................................................................... 112

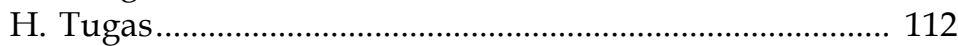

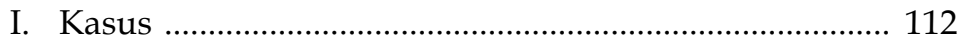

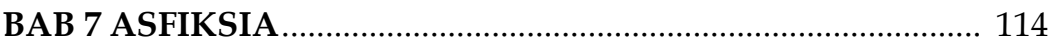

A. Kompetensi akhir yang diharapkan ................................. 114

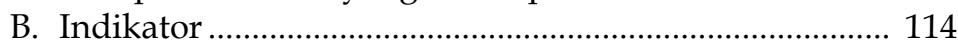

C. Pokok-Pokok Materi ………………………................. 114

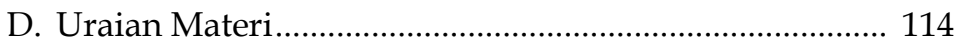

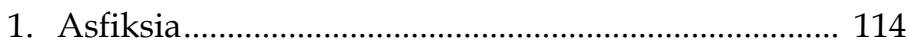

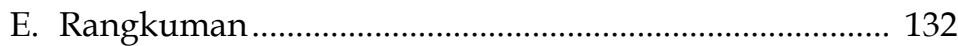

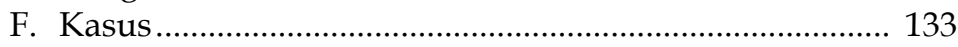

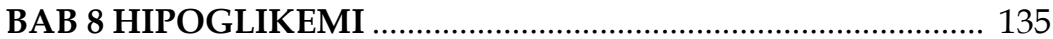

A. Kompetensi akhir yang diharapkan ................................ 135

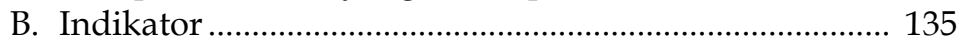

C. Pokok-Pokok Materi …………………………............ 135

D. Uraian Materi..................................................................... 135

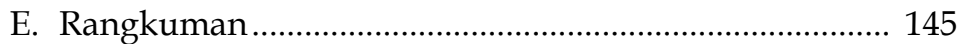

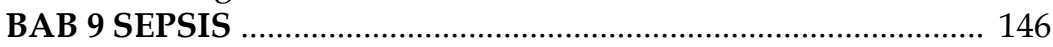

A. Kompetensi akhir yang diharapkan ............................... 146

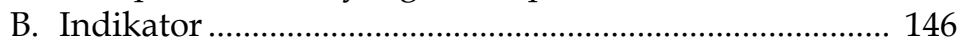

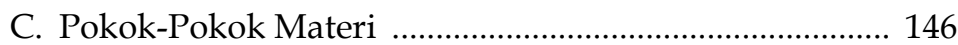

D. Uraian Materi....................................................................... 150

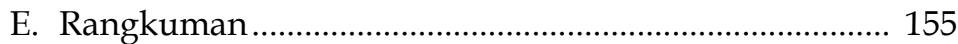

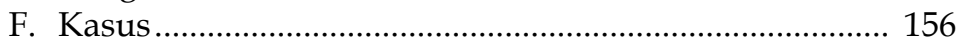




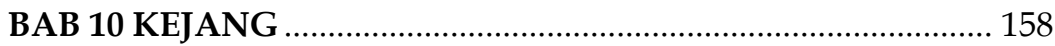

A. Kompetensi akhir yang diharapkan.................................. 158

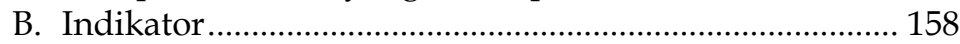

C. Pokok-Pokok Materi ………………………….............. 158

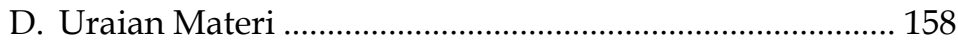

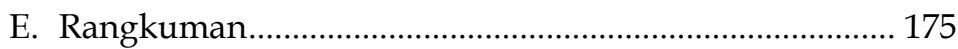

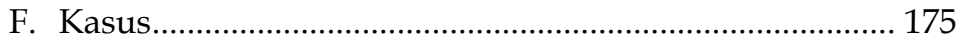

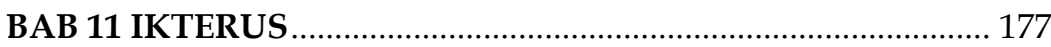

A. Kompetensi akhir yang diharapkan................................ 177

B. Indikator........................................................................... 177

C. Pokok-Pokok Materi ………………………............. 177

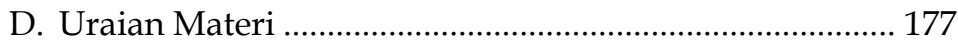

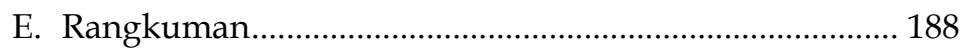

F. Kasus......................................................................... 188

BAB 12 TEKNIK DAN MODEL PENDOKUMENTASIAN

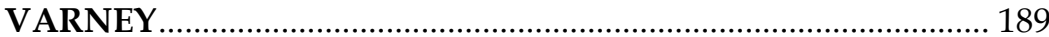

A. Kompetensi akhir yang diharapkan................................ 189

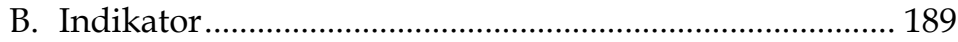

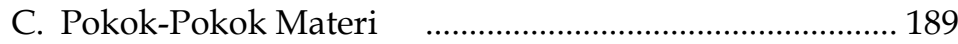

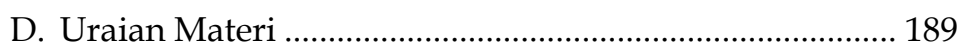

E. Rangkuman..................................................................... 202

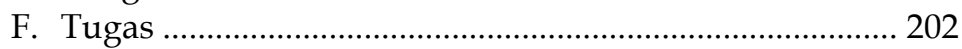

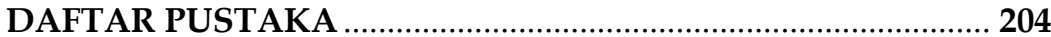




\section{BAB 1 \\ MOLA HIDATIDOSA, KET, ABORTUS}

\section{A. Kompetensi Akhir yang Diharapkan}

Mahasiswa dapat melakukan asuhan kebidanan pada ibu dengan mola hidatidosa, KET, abortus

\section{B. Indikator:}

Penatalaksanaan baru lahir dengan mola hidatidosa, KET, abortus :

1. Persiapan alat

2. Persiapan diri/ bidan

3. Persiapan pasien

4. Persiapan lingkungan

5. Prosedur penatalaksanaan mola hidatidosa, KET, abortus

6. Evaluasi keberhasilan

7. Dokumentasi tindakan

\section{Pokok Materi:}

Mola hidatidosa, KET, abortus

\section{Uraian Materi}

1. Mola Hidatidosa

Awal perkembangan kehamilan dengan mola hidatidosa tidak jauh berbeda dengan kehamilan pada umumnya, yakni timbulnya mual, muntah, serta pusing akan tetapi derajat keluhan yang dirasakan lebih kuat. Gejala lain yang timbul yakni perdarahan yang terjadi secara umum pada usia kehamilan 12-14 minggu dengan sifat perdarahan dapat terjadi secara intermitten, sedikit atau dalam jumlah banyak sekaligus yang dapat mengakibatkan anemia, syok bahkan kematian. Hal yang memperkuat dugaan mola Ketika pengeluaran darah yakni adanya gelembung mola seperti anggur. 
Pengelolaan kasus mola, secara umum sebagai berikut:

a. Pemulihan keadaan umum

b. Pembersihan jaringan mola yang dilaksanakan di rumah sakit menggunakan 2 cara yakni vakum kuretase dan histerektomi.

c. Pemeriksaan tindak lanjut.

Kehamilan mola yang berakhir dengan kematian disebabkan oleh perdarahan, infeksi, payah jantung atau tirotoksikosis.

2. Kehamilan Ektopik Terganggu (KET)

Kehamilan ektopik merupakan suatu kondisi ketika hasil pembuahan mengalami implantasi akan tetapi bukan di dinding endometrium kavum uteri, yang sering ditemukan yakni di saluran telur (tuba falopii). Pembagian kehamilan ektopik dapat dikategorikan menjadi 5 bagian berdasarkan lokasi terjadinya, yakni kehamilan tuba, kehamilan intraligamenter, kehamilan heteropik (satu janin di kavum uteri, lainnya kehamilan ektopik), kehamilan ektopik bilateral, kehamilan ektopik lain (serviks uteri, ovarium, atau abdominal).

Terjadinya kehamilan ektopik dapat dipicu oleh karena sel telur yang sudah dibuahi mengalami hambatan dalam perjalanannya menuju endometrium. Beberapa faktor yang menjadi penghambat tersebut diantaranya:
a. Faktor tuba
b. Faktor abnormalitas dari zigot
b. Faktor ovarium;
c. Faktor hormonal
d. Faktor lain

Apabila terdapat penyulit pada kehamilan ektopik atau terjadi ruptur maka akan timbul gejala dan tanda yang khas yakni terdapat sakit perut mendadak yang selanjutnya diikuti dengan syok atau pingsan, hal tersebut merupakan 
suatu tanda terjadinya kehamilan ektopik terganggu. Selanjutnya, tanda krusial yang kedua dari kehamilan ektopik terganggu yakni perdarahan pervaginam. Keadaan ini mengindikasikan kematian janin, dan berasal dari kavum uteri berupa pelepasan desidua. Perdarahan yang bersumber dari uterus pada umumnya tidak banyak serta memiliki warna coklat tua. Pada pemeriksaan bimanual terdapat nyeri goyang serviks/slinger pijn (bahasa Belanda). Pada rupture tuba dengan perdarahan banyak dapat terjadi penurunan tekanan darah dan peningkatan nadi.

\section{Abortus}

Abortus atau keguguran merupakan hasil konsepsi yang keluar terjadi saat usia kehamilan kurang dari 20 minggu serta berat janin kurang dari 500 gram. Penyebab terjadinya abortus bermacam-macam dan sering diperdebatkan. Secara umum ada lebih dari satu penyebab, antara lain: faktor genetik, autoimun, kelainan anatomi/ kelainan kongenital uterus, infeksi, hematologik, defek fase luteal, serta lingkungan hormonal. Berikut ini beberapa jenis abortus berdasarkan tanda, gejala dan proses patologi yang terjadi, serta penatalaksanaannya:

a. Abortus imminens; merupakan perdarahan pervaginam sebelum usia kehamilan 20 minggu, tanpa nyeri dan ukuran rahim sesuai dengan usia kehamilan dan leher rahim yang tertutup, tes urin kehamilan masih positif dan hasil konsepsi masih baik. Pasien disarankan untuk tirah baring hingga perdarahan tidak terjadi dan disarankan untuk tidak melakukan hubungan seksual terlebih dulu sampai lebih kurang 2 minggu. Agar dapat dilakukan pemeriksaan lebih lanjut dan mendapatkan penanganan secara medis, pasien dirujuk ke dokter kandungan.

b. Abortus insipiens; kehamilan awal dengan perdarahan vagina dan dilatasi serviks. Biasanya, perdarahan vagina lebih buruk dibandingkan dengan aborsi mengancam, 
dan lebih banyak kram yang dirasakan pasien, serta belum ada jaringan yang keluar. Pada USG, hasil konsepsi terletak di segmen bawah rahim atau saluran serviks. Besar uterus masih sesuai dengan umur kehamilan dan tes urin kehamilan masih positif. Kontraksi yang kuat dan sering pada umumnya dikeluhkan oleh pasien, serta pengeluaran darah yang bertambah sesuai dengan pembukaan serviks dan usia kehamilan. Penanganan pada pasien bidan harus memperhatikan keadaan umum dan perubahan keadaan dinamika aliran darah yang terjadi kemudian secepatnya dilaksanakan tindakan perbaikan keadaan umum serta dilakukan rujukan untuk menegaskan kondisi abortus (melalui pengecekan USG) dan evakuasi/pengeluaran hasil konsepsi dengan digital kemudian dilakukan kuretase jika darah yang keluar banyak dan diberikan uterotonika. Perawatan setelah tindakan antara lain kontrol keadaan umum pasien, pemberian uterotonika dan antibiotika profilaksis lewat advice dokter, konseling pemenuhan kebutuhan nutrisi/hidrasi, eliminasi, mobilisasi, hygiene, dan kontrasepsi.

c. Abortus inkompletus; kehamilan yang berhubungan dengan perdarahan vagina, dilatasi saluran serviks, dan keluarnya hasil konsepsi. Pada umumnya pasien merasakan kram yang hebat, dan perdarahan vagina sangat berat. Pasien dapat menjelaskan terdapat jaringan yang telah keluar, atau pemeriksa dapat mengamati bukti bahwa jaringan yang telah keluar di dalam vagina. Pemeriksaan USG dapat menunjukkan bahwa beberapa hasil konsepsi masih ada di dalam rahim. Pada pemeriksaan ukuran uterus lebih kecil dari usia kehamilan, kanalis servikalis masih terbuka, teraba jaringan/menonjol pada ostium uteri eksternum, perdarahan bisa sedikit sampai banyak tergantung pada jaringan yang tersisa. Pasien dapat mengalami anemia atau syok hemoragik sebelum sisa konsepsi dikeluarkan. 
Penatalaksanaan pasien terlebih dahulu memperhatikan keadaan umum dan menanggulangi gangguan dinamika aliran darah kemudian dilanjutkan dengan rujukan untuk menetapkan diagnosis klinis (melalui USG apabila diperlukan) serta pelaksanaan kuretase dengan hati-hati sesuai keadaan umum dan ukuran uterus.

d. Abortus kompletus; ketika ada perdarahan vagina dan keluarnya hasil konsepsi melalui serviks. Pada USG transvaginal, tidak akan ada sisa hasil konsepsi di dalam rahim. Abortus ini ditandai dengan ostium uteri yang telah menutup, besar uterus lebih kecil dari usia kehamilan, perdarahan sedikit dan seluruh hasil konsepsi telah keluar, pemeriksaan urin pada umumnya masih positif hingga 7-10 hari setelah abortus. Penatalaksanaan pasien tidak membutuhkan perawatan atau tata laksana khusus. Pasien dapat diberikan raborantia apabila dibutuhkan dan dilakukan konseling pemenuhan kebutuhan pasca abortus.

e. Missed abortion; abortus yang memiliki ciri-ciri sebelum usia kehamilan 20 minggu, fetus telah meninggal dalam kandungan serta hasil konsepsi masih ada di dalam kandungan. Pada umumnya pasien tidak mengeluhkan apapun kecuali pertumbuhan kehamilannya tidak seperti yang diharapkan. Ketika usia kehamilan 14-20 minggu pasien merasakan rahimnya semakin kecil dengan tandatanda kehamilan sekunder mulai menghilang, tes urin kehamilan negative pada 1 minggu setelah terjadinya abortus. Penatalaksanaan meliputi penanganan awal antara lain evaluasi keadaan umum dan kondisi klinis kemudian dilaksanakan rujukan untuk penentuan diagnosis serta penanganan evakuasi hasil konsepsi (dilatasi dan kuretase dengan meninjau kondisi ibu dan kondisi kehamilan). Peluang timbulnya penyulit pada tindakan missed abortion ini lebih tinggi dikarenakan jaringan plasenta yang menempel pada dinding uterus pada umumnya lebih kuat. 
f. Abortus habitualis; merupakan abortus spontan yang terjadi 3 kali atau lebih secara berturut-turut, secara umum pasien yang mengalami abortus habitualis tidak mengalami kendala untuk dapat hamil kembali, tetapi berakhir dengan abortus. Salah satu factor paling sering ditemukan yang menyebabkan abortus habitualis yakni inkompetensi serviks yaitu keadaan dimana serviks tidak mampu menerima beban untuk tetap bertahan menutup setelah kehamilan melewati trimester pertama, dimana ostium serviks akan membuka tanpa disertai rasa mules/kontraksi Rahim dan akhirnya terjadi pengeluaran janin.

g. Abortus infeksiosa, Abortus Septik; adalah abortus yang disertai infeksi pada alat genitalia, sedangkan abortus septik penyebaran nfeksi sudah mencapai peredaran darah tubuh atau peritoneum. Tanda gejala yang dapat ditemukan pada pemeriksaan antara lain panas tinggi, tampak sakit dan lelah, adanya takikardia, perdarahan pervaginam yang menimbulkan bau, uterus yang membesar dan lembek, serta nyeri tekan, pada pemeriksaan laboratorium didapatkan leukositosis. Apabila hal tersebut berlanjut hingga terjadi sepsis dan syok, penderita akan tampak lelah, panas tinggi, menggigil dan tekanan darah turun. Penatalaksanaan pada pasien dengan kondisi seperti ini harus memperhitungkan keadaan umum dan rujukan segera untuk memenuhi keseimbangan cairan tubuh dan perlunya pemberian antibiotika yang adekuat sesuai hasil kultur. Tindakan kuretase disertai pemberian uterotonika dapat diberikan apabila keadaan tubuh berangsur membaik minimal 6 jam setelah antibiotika adekuat diberikan.

h. Kehamilan anembrionik (Blighted Ovum); merupakan suatu kondisi dalam kehamilan patologi ketika janin dan yolk sac mengalami gangguan untuk dapat terbentuk sejak awal walaupun kantong gestasi tetap terbentuk. 
Kehamilan tetap berjalan hingga usia 14-16 minggu walaupun tidak terdapat janin didalamnya. Kehamilan anembrionik dapat diketahui melalui pemeriksaan USG yang dilaksanakan pada usia kehamilan 7-8 minggu. Rujukan harus segera dilakukan apabila pada deteksi dini usia kehamilan 12 minggu atau lebih belum teridentifikasinya DJJ dengan Doppler. Penatalaksanaan kondisi dengan kehamilan ini dilakukan melalui terminasi kehamilan dengan dilatasi dan kuretase secara elektif.

\begin{tabular}{|c|c|c|c|c|c|}
\hline $\begin{array}{r}\text { PENUNT } \\
\text { ASUHAN KEBIDANA } \\
\text { PERDARAHA }\end{array}$ & A & $\mathbf{A I}$ & $\begin{array}{l}\text { R } \\
\text { SIEI } \\
\text { MUD }\end{array}$ & DEI & AN \\
\hline $\begin{array}{l}\text { Penilaian } \\
0 \text { : gagal (bila langkah klinik }\end{array}$ & 0 & lak & & & \\
\hline $\begin{array}{r}1: \text { kurang ( langkah klinik } \\
\text { mendemonstrasikan sest }\end{array}$ & & & $\begin{array}{l}\text { tetap } \\
\text { rose }\end{array}$ & $\begin{array}{l}\text { tidal } \\
\text { ur ) }\end{array}$ & mampu \\
\hline $\begin{array}{l}2 \text { : cukup (langkah klini } \\
\text { kurang, atau } \\
\text { mendemonstrasikan dar } \\
\text { lebih lama untuk menye }\end{array}$ & ke & $\mathrm{aka}$ & $\begin{array}{l}\mathrm{n} \text { de } \\
\text { cekc } \\
\text { g di } \\
\text { tu tu }\end{array}$ & $\begin{array}{l}\text { engan } \\
\text { tan } \\
\text { perluk } \\
\text { gas) }\end{array}$ & $\begin{array}{r}\text { bantuan, } \\
\text { dalam } \\
\text { in relatif }\end{array}$ \\
\hline $\begin{array}{r}3 \text { : } \text { baik ( langkah klinik dil } \\
\text { percaya diri, kadang } \\
\text { memerlukan wakt } \\
\text { pertanggungjawabkan) }\end{array}$ & $\overline{a n}$ & len & mpa & $\begin{array}{r}\text { antuar } \\
\text { k cen } \\
\text { dapa }\end{array}$ & $\begin{array}{r}\text { kurang } \\
\text { as dan } \\
\text { di }\end{array}$ \\
\hline $\begin{array}{c}4 \text { : sangat baik ( langkah kli } \\
\text { tepat sesuai dengan t } \\
\text { kebidanan dan waktu ef }\end{array}$ & & & in de & $\begin{array}{l}\text { ngan b } \\
\text { dalam }\end{array}$ & $\begin{array}{l}\text { enar dan } \\
\text { lingkup }\end{array}$ \\
\hline I & & & Nila & & $\mathrm{Vat}$ \\
\hline Langkan & 0 & 1 & 2 & \begin{tabular}{l|l}
3 & 4
\end{tabular} & Ket. \\
\hline $\begin{array}{l}\text { 1. PERSIAPAN ALAT } \\
\text { a. Buku KIA/status ibu } \\
\text { hamil } \\
\text { b. Pena } \\
\text { c. Kalender kehamilan } \\
\text { d. Baki dan alas } \\
\text { e. Alas bokong } \\
\text { f. Sphygmomanometer } \\
\text { g. Stetoskop }\end{array}$ & & & & & \\
\hline
\end{tabular}




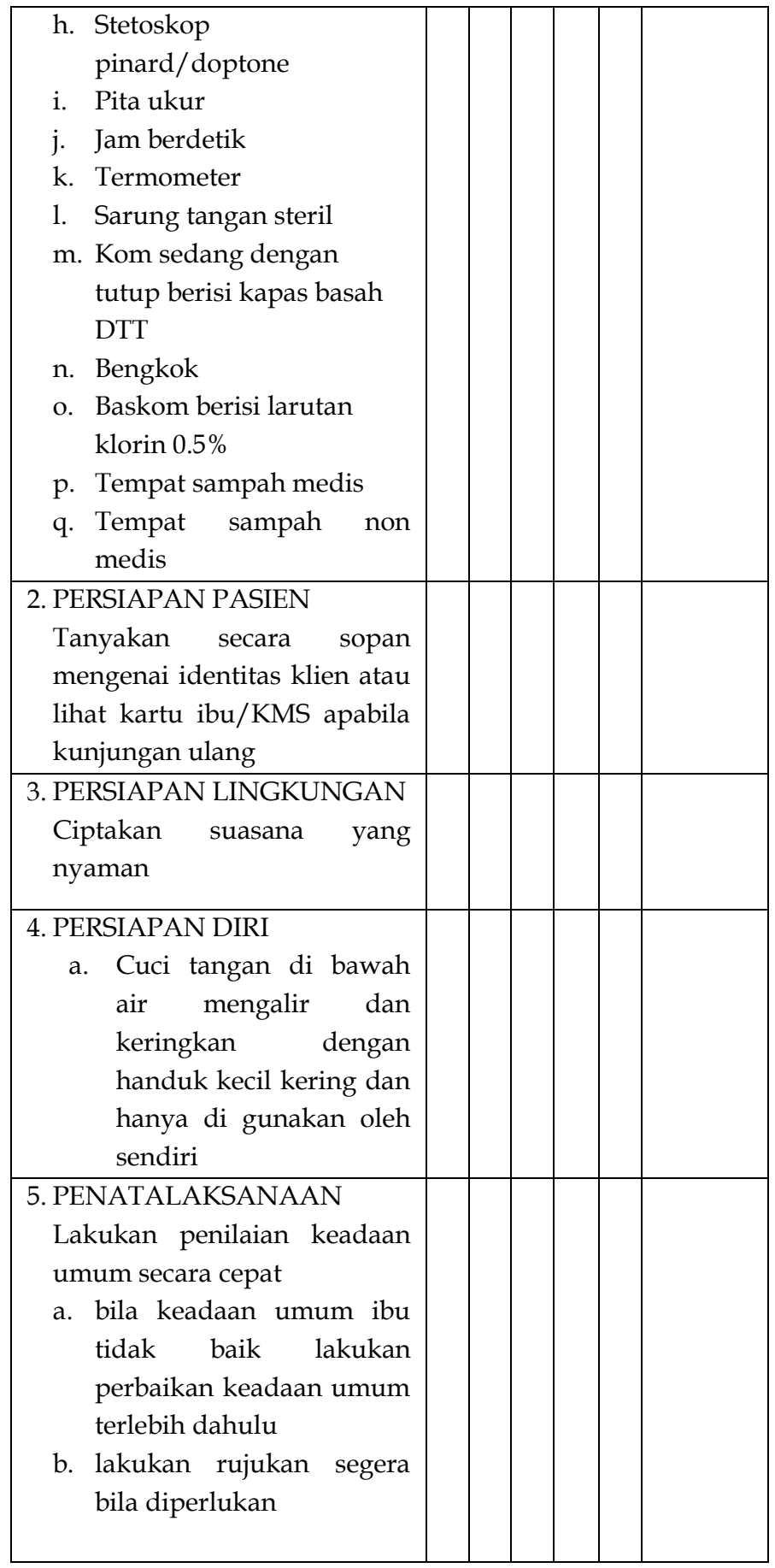




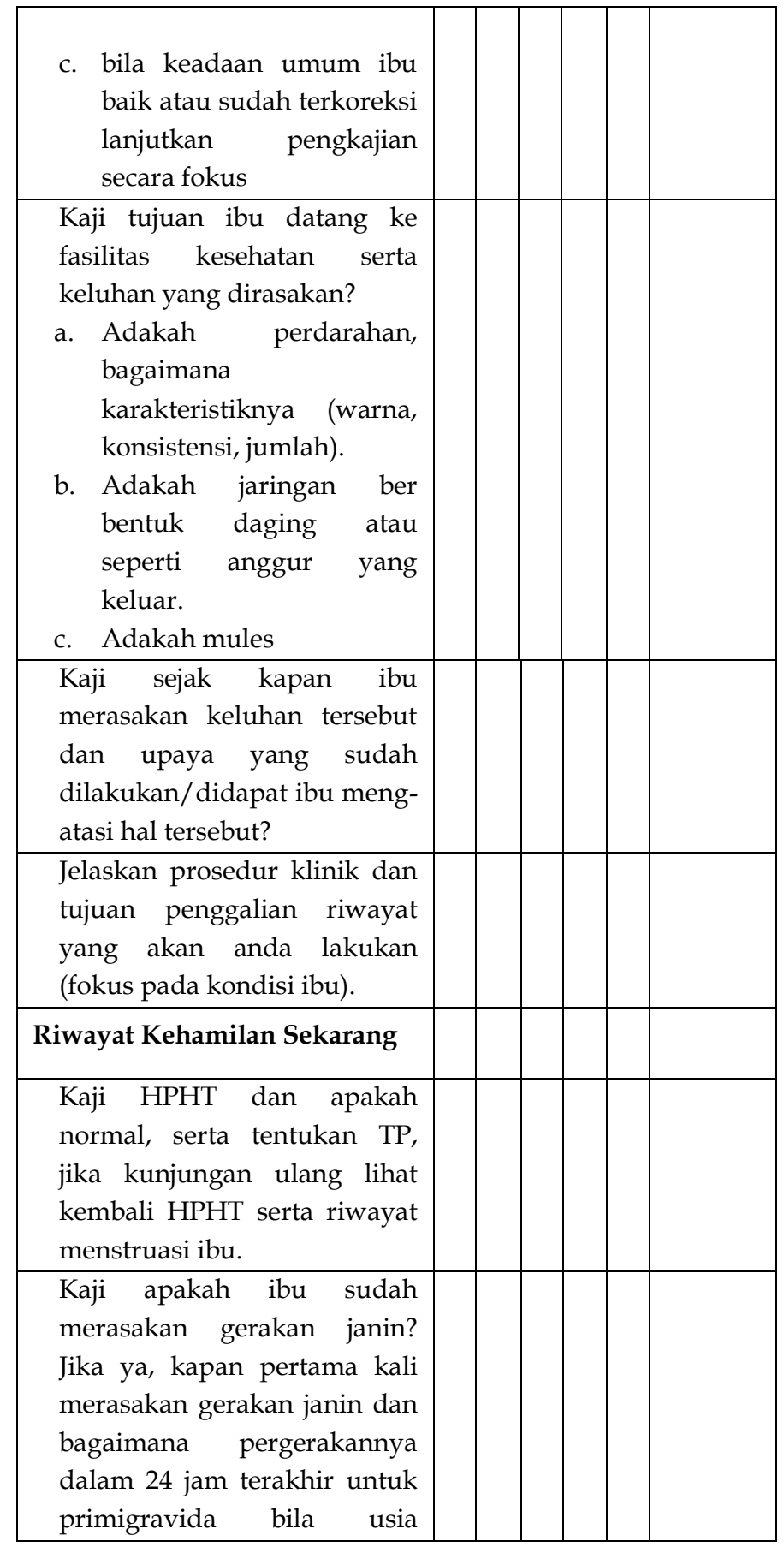




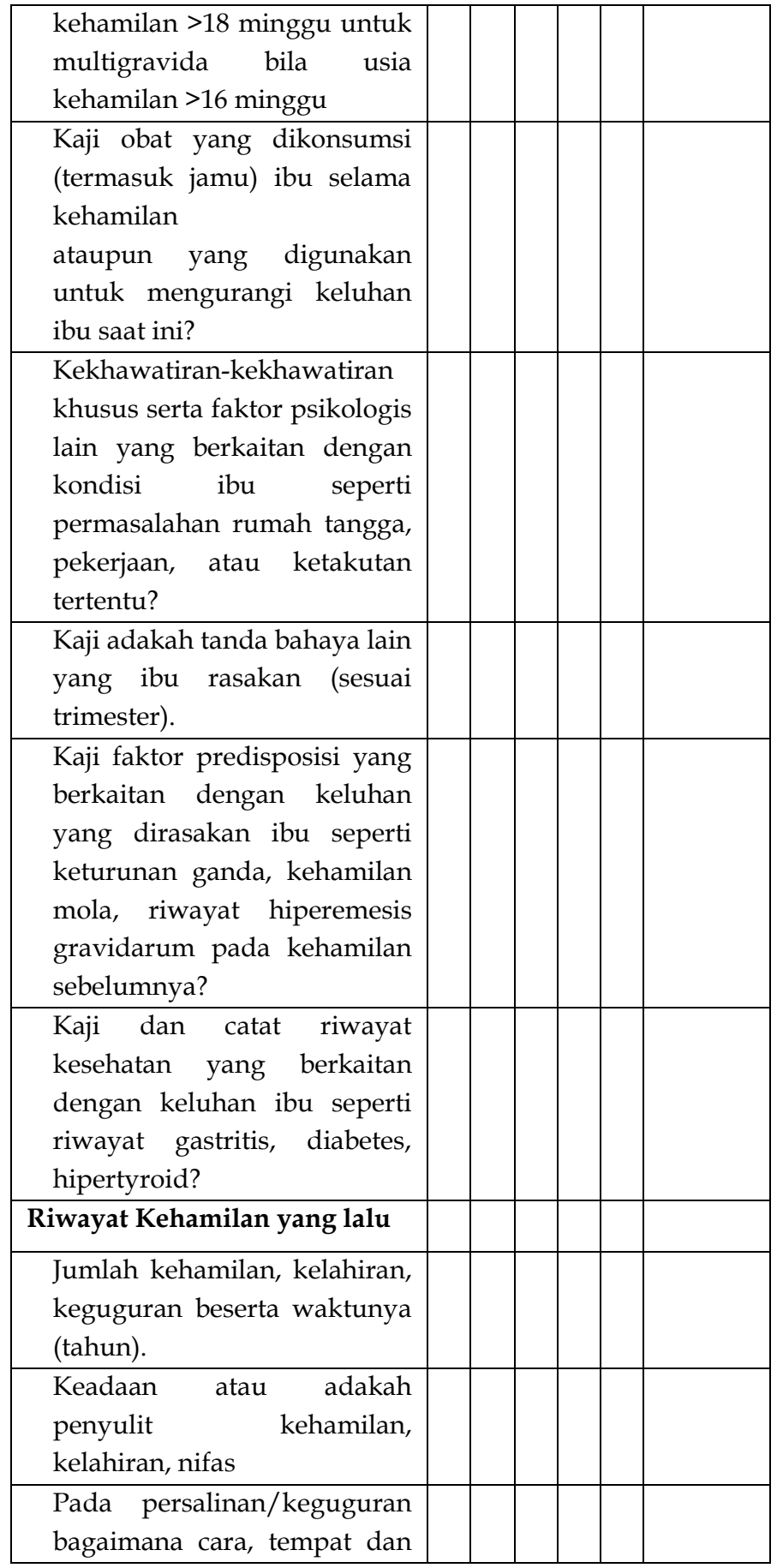




\begin{tabular}{|c|c|c|c|c|c|c|}
\hline penolong & & & & & & \\
\hline $\begin{array}{l}\text { Bayi baru lahir meliputi jenis } \\
\text { kelamin, BB/PB, keadaan } \\
\text { anak }\end{array}$ & & & & & & \\
\hline Riwayat Kesehatan & & & & & & \\
\hline $\begin{array}{l}\text { Adakah penyakit penyakit } \\
\text { degenerative, penyakit } \\
\text { menular, penyakit keganasan } \\
\text { yang sedang diderita atau } \\
\text { sedang dalam pengobatan }\end{array}$ & & & & & & \\
\hline Kegiatan Sehari-hari & & & & & & \\
\hline Diet/nutrisi yang dikonsumsi & & & & & & \\
\hline Eliminasi (BAK dan BAB) & & & & & & \\
\hline Istirahat dan tidur & & & & & & \\
\hline Mobilisasi & & & & & & \\
\hline Beban kerja & & & & & & \\
\hline Riwayat Psikososial Budaya & & & & & & \\
\hline $\begin{array}{l}\text { Apakah kehamilan ini } \\
\text { direncanakan }\end{array}$ & & & & & & \\
\hline & & & $\overline{\mathrm{AS}}$ & & & \\
\hline LANGKAH & $\mathbf{0}$ & 1 & 2 & 3 & 4 & net. \\
\hline $\begin{array}{l}\text { Bagaimana penerimaan/ } \\
\text { dukungan suami dan keluarga } \\
\text { terhadap kehamilan }\end{array}$ & & & & & & \\
\hline $\begin{array}{l}\text { Apakah ada mitos/budaya yang } \\
\text { selama kehamilan ini dijalankan } \\
\text { oleh ibu. } \\
\text { Jelaskan bahwa pengumpulan } \\
\text { data subjektif sudah selesai dan } \\
\text { akan dilanjutkan dengan } \\
\text { pemeriksaan fisik, tanyakan } \\
\text { bilamana ada hal yang masih } \\
\text { ingin ditanyakan oleh ibu. }\end{array}$ & & & & & & \\
\hline $\begin{array}{l}\text { PEMERIKSAAN FISIK } \\
\text { Jelaskan alasan akan dilakukan } \\
\text { beberapa pemeriksaan dan }\end{array}$ & & & & & & \\
\hline
\end{tabular}




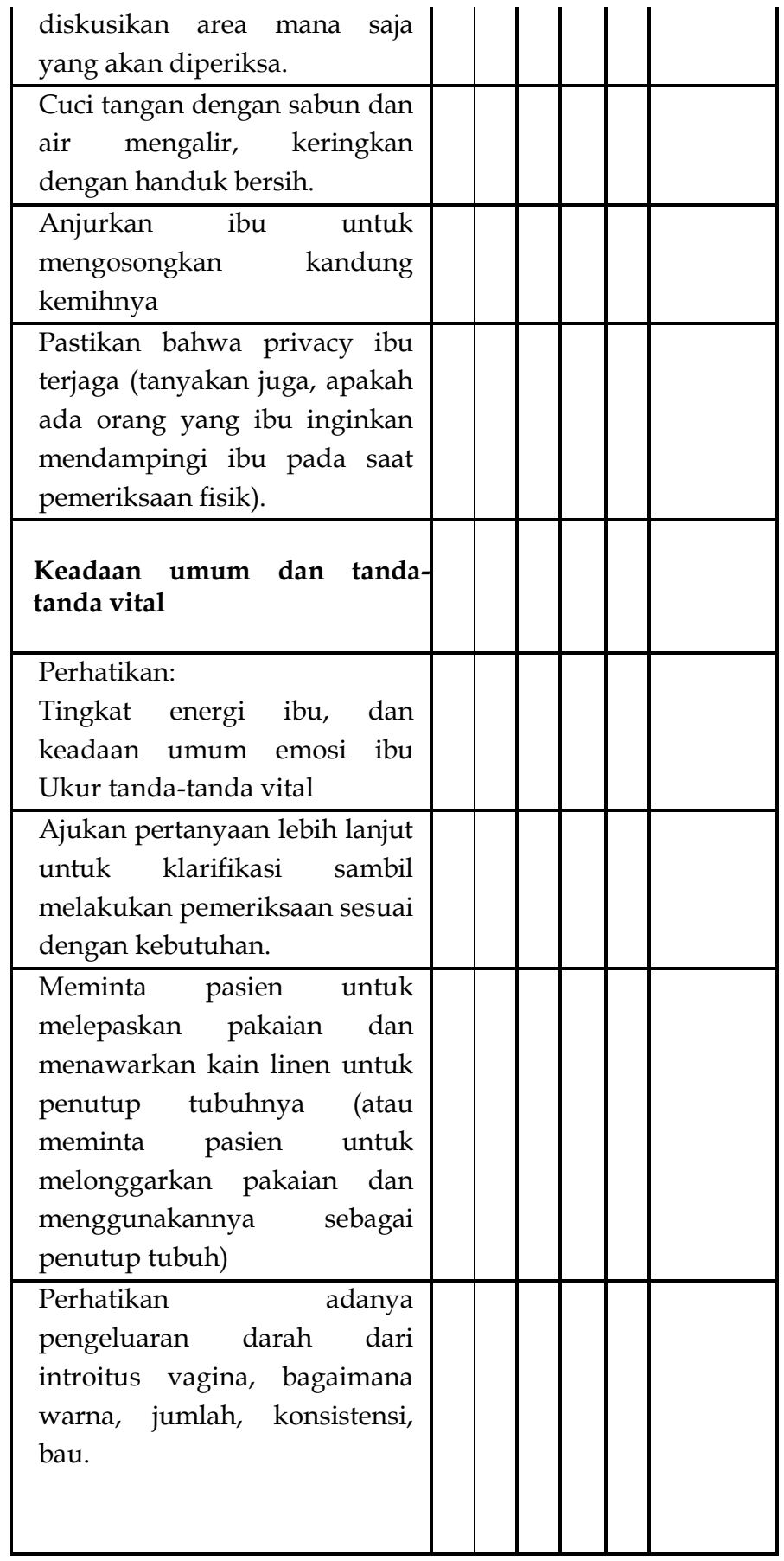




\begin{tabular}{|c|c|c|c|c|c|c|}
\hline Kepala & & & & & & \\
\hline $\begin{array}{l}\text { Periksa mata untuk melihat } \\
\text { apakah: } \\
\text { Pucat pada kelopak bagian } \\
\text { bawah } \\
\text { Berwarna kuning pada sclera } \\
\text { Periksa bibir, apakah pucat }\end{array}$ & & & & & & \\
\hline Abdomen & & & & & & \\
\hline $\begin{array}{l}\text { Periksa, apakah ada bekas luka } \\
\text { operasi. }\end{array}$ & & & & & & \\
\hline $\begin{array}{l}\text { Palpasi abdomen, untuk } \\
\text { pemeriksaan: } \\
\text { Kelembutan (konsistensi) } \\
\text { Massa } \\
\text { Suprapubis tenderness }\end{array}$ & & & & & & \\
\hline $\begin{array}{l}\text { Ukur tinggi fundus uteri. } \\
\text { Gunakan jari tangan (kalau } \\
<20 \text { minggu) atau pita ukuran } \\
(\text { kalau >22 minggu). } \\
\text { Bandingkan tinggi fundus } \\
\text { hasil pengukuran dengan } \\
\text { perkiraan tinggi fundus } \\
\text { berdasarkan usia kehamilan. }\end{array}$ & & & & & & \\
\hline & & & Vila & & & Ket \\
\hline Langkah & 0 & 1 & 2 & 3 & 4 & Ket. \\
\hline $\begin{array}{l}\text { Dengarkan denyut jantung } \\
\text { janin (dengan Doppler bila }>12 \\
\text { minggu dan fetoskop kalau } \\
>20 \text { minggu) selama satu menit } \\
\text { dan hitung. }\end{array}$ & & & & & & \\
\hline Apakah teraba ballotement. & & & & & & \\
\hline Apakah teraba gerakan janin. & & & & & & \\
\hline $\begin{array}{l}\text { Apakah ada nyeri saat palpasi } \\
\text { abdominal, bagian mana. }\end{array}$ & & & & & & \\
\hline
\end{tabular}

